\title{
Cost-Benefit Analysis Of Downtown Renewal In Troy, New York
}

\author{
Donald F. Vitaliano*
}

I. Introduction

An increasing number of cities are attempting to use urban renewal to stem what they see as the deterioration of their central business district (CBD), manifested by physical deterioration of commercial structures and growing numbers of vacant shops. One such city is Troy, New York, population 62,000 (1970), located in upstate New York about ten miles north of Albany, the state capital, and about 10 miles east of Schenectady. These three cities comprise the Capital District Region. Troy flourished in the early nineteenth century because of its strategic location at the headwaters of the Hudson River and the eastern end of the Erie Canal. Population peaked around 1910 and has been declining since. Befitting its Nineteenth Century status and prosperity, Troy developed a bustling downtown business district, filled with rows of shops, newspapers, trolley lines, etc. Indeed, it was a classic Nineteenth Century city. Since World War II, the decline in Troy's downtown has been obvious. The erosion of its economic base, the suburbanization of population and shopping left Troy with fourteen percent of its CBD ground floor retail space vacant in 1969. ${ }^{1}$ The upper stories of many downtown commercial buildings are vacant. Little new construction, aside from recent urban renewal, has taken place in the core. Most of the buildings are between seventy-five and one hundred years old.

\section{Description of the Project}

In an attempt to reverse the tide of CBD decay, Troy has begun a major program of federally-aided urban renewal. Encompassing about 42 of the 115 acres of the CBD, the project contemplates demolition of about fifteen acres of nonresidential structures in the $80-100 \%$ business core and about two acres of residential buildings on the fringe of the CBD. An enclosed suburban-type shopping mall with multi-level parking garages will form the new commercial core. A mixture of publicly-assisted/private housing is planned in the residential development area. Another five acres of the project area is designated for conservation, with selected rehabilitation of certain residential structures. The remainder of the project area is vacant land and streets and alleys. The southern edge of the project is the site of a new city hall, the old one having burned down in 1938. Demolition began in 1973 and the project is expected to be built in three stages and fully operational by 1980.

The object of this paper is to undertake an efficiency cost-benefit analysis of this renewal project. Up to now, cost-benefit studies of urban renewal have

*Associate Professor of Economics, Rensselaer Polytechnic Institute, Troy, New York 12181. 
been done well after the projects have been completed. ${ }^{2}$ The present prospective analysis is therefore predictive as much as it is analytical. In addition, as Weicher notes, "there has been virtually no systematic investigation of the magnitude, or even the existence, of the benefits which theoretically arise from commercial renewal." 3 This study is an attempt to close this gap in our understanding. Limitations of space and time dictate that attention be directed solely to the commercial aspect of the project. Residential renewal has been widely written about and little interaction between the commercial and residential phases seems likely, especially given the marginal nature of the latter to the present project. The city hall project may also be detached without harm and regarded as an ordinary public project, unrelated to renewal. The site for the new city hall was chosen primarily so that part of its costs could count toward the city's share of project costs.

\section{Causes of Downtown Decay ${ }^{4}$}

Urban land use is most efficient when the structures placed on each site are those whose present value of discounted net returns are the highest of all alternative uses of the site. Competition among land users will assure that landowners will receive any locational rents unique to any particular site. The building owner (if we separate the two roles conceptually) will receive only a normal profit, but the highest bidder for the land will get to use it and construct the most suitable structure upon it. Like any piece of long-lived capital equipment, structures run the risk of economic obsolescence. If the decision were being made today about what to put on a site, the same structure would not be built. The present value of the expected net revenues no longer justify the replacement cost of the structure. That land use patterns change considerably over time is seen by the simple observation that rarely are demolished structures replaced by new versions of what previously occupied the site. Economic obsolescence does not imply that such structures should necessarily be torn down. Once erected, their market value will be price determined by the market demand for the services they provide. The building's value will be the discounted value of the stream of earnings net of operating costs. Economic obsolescence is given by the fact that these net returns do not cover depreciation at replacement cost plus normal profit." It will be privately profitable to replace a structure only when the stream of net earnings expected from the new use are sufficiently large to permit recovery of the cost of the new structure, plus the cost of the old structure (including demolition cost). The cost of the old structure represents the present value of the stream of economic services it provides. It would, thus, appear that the unfettered private market can provide an optimal pattern and timing of land use. Needless to say, this optima may be characterized by esthetically unappealing land use and/or building design, e.g. garnish fastfood establishments, gasoline stations, teenage bars, etc. When the demand for a building's services decline sufficiently, the owner will be driven by the profit motive to demolish and replace with more suitable modern structures. The decline of downtown Troy, and many other cities, can be fitted into this theoretical framework.

The advent of the automobile and the growth of large scale, self-service retailing have seriously eroded the demand for downtown shopping. ${ }^{6}$ The auto has 
promoted suburbanization of the population with a resultant suburbanization of retailing in order to be accessible to shoppers and permit vast parking areas. Suburbanization has also reduced the relative economic status of those for whom the CBD shopping trip is most convenient. The median family income of groups living in and near Troy has fallen over time relative to the county and SMSA levels. Geographic areas north and east of Troy for whom Troy is most accessible for shopping have also lagged behind economically the rest of the SMSA. Thus, those for whom Troy remains the best place to shop are more likely to be relatively poor: the elderly, minority groups, poorly educated blue-collar whites, and rural folks. These groups do not have the income and taste patterns to support the diversified mix of small shop, speciality stores that characterized downtown Troy. Supportive to these tendencies are technological changes on the supply side that render uneconomic major conversion of the existing stock of buildings to contemporary retailing. The present stock of buildings is characterized by narrow frontage, separated by load-bearing masonary walls, under diverse ownership. The cost and/or technical feasibility of breaking through adjoining buildings to provide the large open areas dictated by modern retailing are prohibitive. The advent of auto-age retailing has also rendered the public capital of Troy's CBD obsolete. Streets are narrow and parking is inadequate. Thus, the owners of downtown property, land and buildings have been confronted by a relative and perhaps absolute decline in demand for their services. This manifests itself in high vacancy rates, abandoned structures and declining (relative and perhaps absolutely) property values. None of this is necessarily bad, but certain institutional arrangements, failure of the market to allow for all effects and the long time required for adjustment may justify intervention to alter the pattern of purely private decision making.

\section{Benefits}

Two fundamental notions, both well-rooted in cost-benefit analysis, form the foundation of our inquiry. First, benefits are comprised of the value of resources released by any investment for use elsewhere in the economy. Likewise, costs are the value of resources whose use elsewhere in the economy are foreclosed by their use here. Second, a project is deemed efficient if it creates more value (benefits) than it uses up (costs), both appropriately discounted. That is, if real income is increased. This follows from what Mishan labels the "potentialPareto" criteria. ${ }^{7}$ If the potential beneficiaries of an investment project could compensate the losers and still be better off, the project makes possible an improvement in social welfare. The question of income distribution (who gains and loses) is, of course, important for final project selection by decision makers. Cost-benefit analysis must be sharply contrasted with the financial feasibility studies carried out by project planners and decision makers. Such studies typically deal with purely financial accounting and seek only to determine if adequate funding is available from public and private sources to assure successful completion and operation of the project.

Residential urban renewal real income benefits have been conceived as arising largely from correction of imperfections in urban property markets and re- 
duction in social costs of slums. ${ }^{8}$ The so-called prisoner's dilemma of interdependent property maintenance decisions leading to less than optimal housing investment and difficulty of private land assembly fall under the imperfections heading, while reduced crime, fire, and disease caused by improved housing conditions comprise the second class of possible benefits. Divergences between social and private product resulting from these factors could cause a privately unprofitable project to be socially worthwhile. Largely due to work by Rothenberg, measurement of market failure centers about changes in land values caused by renewal projects. ${ }^{9}$ Large scale land assembly by a public body overcomes the prisoner's dilemma and the holdout problem of private redevelopment. The resulting increase in land productivity can be approximated by measuring the change in land values on and off the project site-with proper allowance for taxes and purely pecuniary land value changes. Measurement of social cost changes is only sketched by Rothenberg, but one writer has used multiple regression analysis with some success. ${ }^{10}$

Unfortunately, the analytical framework developed for evaluating residential renewal projects does not appear to be very helpful in analyzing commercial projects. The incerdependence of maintenance decisions appears much less important for business and commercial properties than for residential neighborhoods. In fact, more than interdependence is required; the matrix of investment alternatives must assume a particular concatenation in order for suboptimality to exist. ${ }^{11}$ As for land assembly problems, the almost complete private renewal of the east side of Manhattan in New York City since 1945 is testimony to the ingenuity of developers in assembling sites, given sufficient profit incentive. Nevertheless, the internalization of external effects as a source of aggregate social benefits cannot be dismissed out-of-hand. It seems reasonable to assume that, other things equal, large properties would be more valuable on a per square foot basis than smaller lots if the land assembly and interdependence factors are truly significant. To test this hypothesis, a sample of one hundred properties in the Troy CBD was collected and the estimated market price per square foot of land was regressed against straight line distance (in feet) from the block of highest value and the size of the lot (in square feet). Three forms of the regression were run: ${ }^{12}$ all variables in natural units, the independent variables in natural log units and all variables in natural logs. ${ }^{13}$ In all cases, the constant term and the distance coefficent were significant, indicating the importance of certrality, the $\mathrm{R}$ squared is acceptable for the log forms. In no case was the lot size variable significant at the five percent level, not even the sign was in the expected direction. The range of variation in lot size was substantial, approaching in some cases the size of the redevelopment parcels assembled by urban renwal. It does not appear as if the market in Troy places any particular premium on land assembled into larger chunks. Further, the impression one gets is that property owners are eager to dispose of their holdings to willing buyers. One group of owners of business property in an area contiguous to the project strongly requested inclusion in urban renewal. Lack of federal funds made this impossible and their disappointment was keenly expressed in the media.

If correction of market imperfections is not likely to generate social benefits, what other factors then might warrrant public subsidy for urban renewal in 
Troy? The local authorities lay great stress on two effects of the project: "revitalizing" downtown Troy and increasing the sales and property taxes collected by the city government.

What exactly is meant by revitalizing downtown Troy is not clear, let alone its being a benefit. Removing so-called blighted structures is one possible aspect, improving the appearance of the city. But against this must be noted a growing feeling, not just in Troy, but nationally, that the wholesale demolition of blocks of distinctive 19th century commercial structures involves society in a cost, not a benefit. A non-trivial amount of criticism from historical preservation groups, planners and architects has been leveled at the renewal project in Troy on these grounds. A few structures on the National Register are being retained, but otherwise everything else is being swept away. As Ada Louise Huxtable points out, the retention of one or two historically significant buildings in the midst of a redevelopment site does not preserve the character of the place. ${ }^{14}$ It is likely that units no smaller than a city block must be retained to preserve the entire fabric of appearance and charm that a group of buildings conveys. The whole is greater than the sum of its parts.

Another possible interpretation of revitalization might be the preservation of certain unique sorts of shops, peculiar to older downtown areas. But here, too, renewal will likely have a negative effect. As Berry points out, small businesses are among the most adversely affected by urban renewal. ${ }^{15}$ Their small capitalization makes them vulnerable to failure because of the need to move, often several times, and the general disruption of business during the long gestation period (5-8 years) of most renewal projects. In addition, developers appear less than anxious to rent to the small independent merchant who previously occupied the renewal site. Chainstore units are preferred because of their superior credit ratings, which are typically demanded by banks, insurance companies and other lenders who advance funds to finance shopping centers. As noted in Part VIII below, renewal has had a devastating effect on small business in Troy.

It appears that revitalization is an attempt to halt, indeed to reverse, the competitive deterioration of CBD retailing, vis-a-vis suburban shopping malls and discount department stores. The reconstruction of downtown Troy's retailing district will not increase aggregate retail sales in the metropolitan area as a whole, but rather increase the proportion accounted for by Troy. This is why changes in land values are not a good indicator of any increase in aggregate real income caused by the project. Increases in Troy land values caused by a change in its locational advantage will be offset by declines elsewhere as other areas lose trade to Troy. But there are three potential sources of aggregate income effect resulting from downtown revitalization: increased efficiency of shopping by consumers; reduced cost of producing retail sales on the project site because, say, of the use of new capital or scale economies; and changes in the social costs of fires and crimes. Before turning to these matters in detail, a few words are needed about the fiscal impact of renewal on local government.

City and renewal agency officials clearly regard increased net revenues to the local government with constant tax rates as an unmitigated benefit. Of course, 
there can be no welfare gain or loss by government itself, only on households via the government, since it is merely the apparatus for collective decision making. Increased property taxes collected due to higher value improvements being constructed on the cleared land and increased sales tax revenues because of the greater volume of retail sales within the city are merely part of the non-aggregate transfer of economic activity from other places to Troy and cannot be counted as benefits. Some part of increased property taxes captures the increased value of land or improvements due to any lowering of the real cost of output. But since we measure this effect directly, to enter it here would be doublecounting.

One further "non-benefit" must be identified; namely, the value of new improvements erected on the project site. Only if the resources involved would otherwise have been idle can they be counted as a net social benefit. As an antiunemployment device, urban renewal is too time consuming and clumsy in its planning and execution to permit the assumption of no alternative use of the resources involved. Even if the resources would be otherwise idle, to count their cost as a benefit implies no better alternative public project exists, which seems highly improbable in view of society's many pressing social problems.

\section{Increased Consumer Efficiency}

It is well established in the marketing literature that two forces dominate the consumers' decision-making as to the place to shop: ${ }^{16}$ the relative size of different shopping centers and their relative accessibility to the consumer in terms of travel time and ease of parking. The larger a center, the more likely a consumer is to find what he is looking for and the greater is the probability of a successful trip. Against this must be weighed the cost of travel to different centers, increasing with greater travel time and difficulty of parking. Prior to renewal, Troy had no full-line department store, considered the principal attraction of any shopping center. It has three smallish department-type stores, together totaling only 150,000 square feet of retail space and separated by several blocks from each other. Contrast this with the largest regional shopping center, about ten miles away, in which Sears and Macy's both have full-line stores with almost 500,000 square feet of space between them. Renewed Troy is expected to have at least one, possibly two, full-line department stores, in addition to retaining at least two of the three previously existing outlets. Shoppers will thus find an increased variety of goods more conveniently located that will reduce the time cost of travel to shopping. This represents a real net benefit, not a transfer effect.

Huff has expressed the notion of consumers choosing among different shopping locations formally $\mathrm{as}^{17}$

$$
P_{i j}=\frac{\frac{S_{j}}{T_{i j}^{\lambda}}}{\sum_{j=l}^{n} \frac{S_{j}}{T_{i j}^{\lambda}}}
$$


where $P_{i j}$ is the probability of a consumer located at $i$ shopping at $j$, one of $n$ different shopping places available to him. $S_{j}$ is the size (in square feet) of selling space at the different centers, a proxy for the variety available at each; $\mathrm{T}_{\mathrm{ij}}{ }^{\lambda}$ is the travel time from residence at $i$ to shopping center $j$ and $\lambda$ is a parameter designed to reflect the effect of travel time on different types of shopping trips. Consumers are likely to attach less disutility to time and be willing to travel further to shop for items involving larger outlays, e.g. automobiles, than for small outlay items like toothpaste. Thus, the value of lambda can be expected to be lower in the case of automobiles than for toothpaste. Huff has empirically estimated lambda at about 3 for clothing and furniture shopping, the sorts of items of interest in this paper. ${ }^{18}$ Throughout the rest of this paper, this is the value of lambda employed in all calculations.

Equation (1) is analytically appealing because it captures the main elements of the shopping decision and expresses it in probability terms. The consumer does not shop exclusively in one place, but rather distributes his custom among the several places located within reasonable distance to his home.

The use of this model to estimate the value of more convenient shopping is described next. Downtown Troy competes with eight suburban regional-type shopping centers, almost all less than ten years old and amply provided with parking. Renewed Troy will contain three times the full-line department store square footage as old Troy, and multi-level parking garages to accommodate the ubiquitous automobile. In effect, some consumers will find a larger variety of merchandise located nearer their residence as a result of urban renewal. The benefit of this change is what consumers would be willing to pay rather than do without this improvement. An indifference curve of shopping variety versus travel time is derivable from equation (1). The relative probabilities of the consumer shopping at different places is taken as indicative of the relative utility derived from each place.

In Figure 1 , the quassi-indifference curve $P_{11}$ depicts the various combinations of Troy shopping center size and travel time that are equally satisfactory to a consumer located at $\mathrm{i}=\mathrm{l}$. Held constant along $\mathrm{P}_{11}$ (and all other curves in Figure 1) is the travel time to and size of all competing shopping places. Before renewal this consumer will be at point $\mathrm{A}$ and make 34.5 percent of his shopping goods trips to downtown Troy. Upon renewal, the increased size of Troy will be sufficiently more attractive as compared to the size and location of other places to draw 60.1 percent of his custom, B in Figure 1. One way to measure the benefit of this change to the consumer is to ask what is the maximum distance this shopper would have been willing to travel to get to renewed Troy. This is point $\mathrm{C}$ in Figure 1. Any further distance than twenty minutes and this consumer would be worse off than at $\mathrm{A}$, his initial position. If we know the money value of the extra six minutes the shopper would have been willing to travel, we have an estimate of the benefit of the greater convenience of shopping wrought by urban renewal in Troy. Another way of seeing this is to note that at points A and B in Figure 1, the total travel time to all shopping is the same, but at B, the size of one place (Troy) is greater. Thus, the consumer has a greater utility in- 
come at B than A since the same total shopping effort will generate a wider variety of choice. As the amount of time needed to achieve this greater choice is increased (moving from $\mathrm{B}$ to $\mathrm{C}$ ) his total satisfaction is reduced, until at $\mathrm{C}$ he is no better off than he was with the smaller selection of $\mathrm{A}$.

Figure 1 Shoppers' Indifference Curves

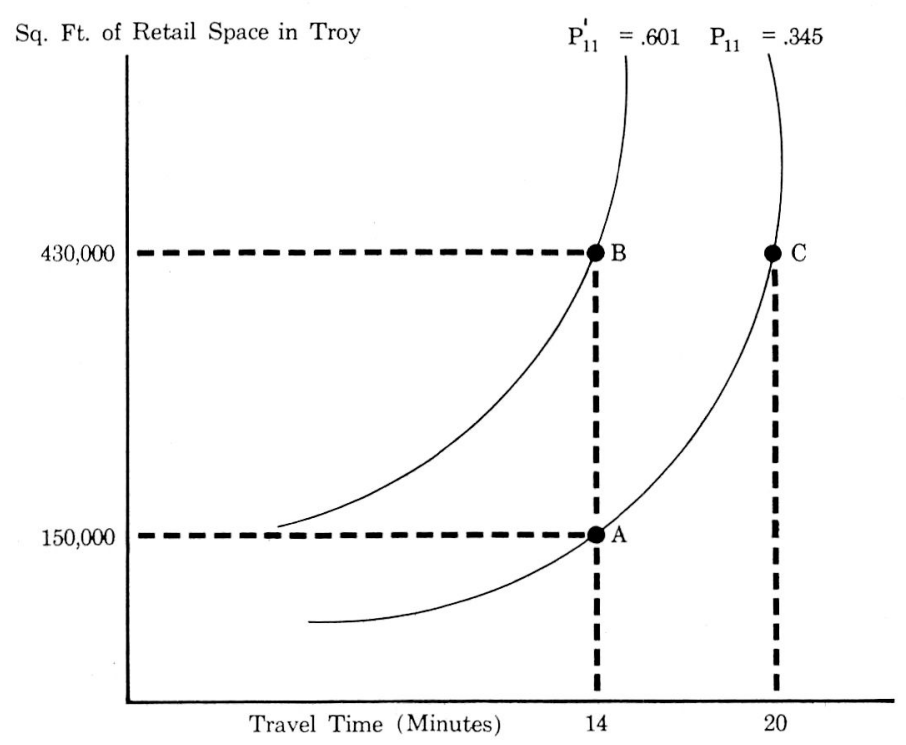

The estimate of shopping benefit was carried out for sixty census tracts in and around Troy, containing 77,785 families in 1970. Each tract was taken as a value of $\mathrm{i}$ in equation (1). Using automobile travel time data compiled by the New York State Department of Transportation, a central traffic analysis node was chosen in each tract. ${ }^{19}$ Average auto travel time for each node to each shopping center was then used, along with the square feet of retail space at each center, to calculate the $\mathrm{P}_{\mathrm{ij}}$ 's for each tract and the maximum benefit travel time for renewed Troy for each tract. To each over-the-road travel time estimate was added 1.5 minutes walking time from the car to the store; two minutes was added to the travel time to renewed Troy and one other center because of the use of garages rather than field parking. ${ }^{20}$

Estimating the value of the time benefit was carried out using the values of travel time saved estimated in the Stanford Research Institute study. ${ }^{21}$ Using over 4000 observations in ten states on toll and free routes, value of travel time was estimated by purpose of trip (work, vacation, social, etc.), income of driver and length of time saving. This latter aspect clearly revealed that the total time saved affected the value per minute, unlike the cruder calculations of travel time per hour formerly available. Generally, time savings less than five minutes were of trivial economic value. This probably reflects a time perception threshold. Median family income in each tract was used to determine the appropriate income level for social-recreational trips in the Stanford study for evaluating maximum time benefit. Each family in each tract was assumed to make two shopping goods trips per month. The proportion of total trips attributed to Troy was 
determined from equation (1) and this number of trips was multiplied by the maximum time benefit value. The result was then doubled to allow for round trips. When this calculation was performed for each of the sixty tracts examined, an annual benefit of $\$ 125,366$ resulted. Discounted at ten percent for twenty years, as of Jan. 1, 1980, this sum is worth $\$ 1,067,382 .^{23}$ This is shown in Table 1 .

\section{Qualifications.}

The preceding analysis is concerned only with automobile trips and assumes two per month. No information could be found on the frequency of trips, so two vehicle trips per month was assumed as a reasonable figure favorable to the project. The calculation is such that total time benefits are proportional to number of trips, so one who believes more or fewer trips are appropriate can adjust the result accordingly. One might expect fewer trips the more remote the location of the consumer's residence. Since the time benefit is greater for more distant locations, the assumption of a uniform number of trips may bias the benefit estimate upwards.

Only automobile trips are considered for several reasons. Studies show relatively few shopping trips arriving at shopping centers via mass transit, even in large cities. ${ }^{24}$ Those who shop by bus (the public transit mode available in Troy) will be largely the poor who do not own cars or the elderly who cannot drive. Few owning automobiles will choose not to avail themselves of the self-scheduling convenience and cargo carrying capacity of their cars. In addition, most of the trading area of Troy is served not at all or poorly by public transportation. Evidence also indicates that the poor place little value on any likely time-saving, a not surprising situation. ${ }^{25}$

Lunch hour, so-called walkin traffic is also not explicitly considered. The reason is that people already in the CBD would not shop elsewhere to seek larger variety, hence they place little value on the greater selection of goods. In addition, the Troy CBD has few sources of employment other than retailing that would generate much walkin traffic; mostly local government, professional offices, banks, etc.

Two further qualifications to the analysis remain to be mentioned: the size of the trade area chosen and the value of improved parking, as contrasted to improved variety of goods. The maximum travel time estimate of an enlarged shopping variety in Troy is based on a comparison with competing centers in the region. Estimates of travel time to Troy are based on the new parking and street improvements and thus make valid the implicit assumption that all the centers vary basically only in size and location, not ease or difficulty of parking. This refers to point B in Figure 1. However, point A is a hypothetical point in the sense it implies the old size of Troy and the new parking, in ordèr to capture the effect of increased variety alone. In effect, there lies to the right of point A and $\mathrm{P}_{\mathrm{ij}}=.345$ another, lower, indifference locus reflecting the old size of Troy and the increased time due to congestion and poor parking. The parking difficulty is estimated by me to be equivalent to three minutes of time and is allowed for in the calculation of the parking garages' costs. ${ }^{26}$

Finally, the trading area of Troy could be extended and perhaps more benefit generated. But the trade area employed here is substantially larger in popula- 
tion and size than that used by the marketing consultant in justifying the private profitability of the shopping mall. Generally, more than ninety percent of shopping trips are generated within a twenty minute driving radius ${ }^{27}$ (the boundary used by the consultant), while the area used here involves travel times up to one hour. Inclusion of more census tracts will generate little additional benefit either because of their remoteness, small population or (in most cases) proximity to other shopping centers.

\section{Increased Efficiency of Output}

If the retailers who occupy the redeveloped site can produce their output (retail sales) more cheaply than in the old structures they formerly occupied, a net saving in resource cost may result. This may manifest itself in higher land prices, greater retailer profits or lower final prices to consumers, depending on market structure and the time period considered. From a global efficiency point of view, it does not matter how the benefits are distributed.

Attempting to measure this increased efficiency by land value changes seems fruitless for several reasons. A substantial part of land value increases (on and off the project site) will be caused by the diversion of shopping to Troy from competing centers. Any such gains in Troy will be offset by losses elsewhere. Secondly, estimating the value of land after redevelopment poses a tangle of problems. The price paid by the developer has little meaning for this purpose since it is determined by bilateral negotiation between the renewal agency and the developer, not through competitive bidding. Indeed, the developer in Troy freely admits the land will be worth substantially more upon project completion than what he is paying for it. ${ }^{28}$ Measuring the change in efficiency of retail output directly seems preferable to attempting to separate it from the welter of forces affecting project land values.

Since redevelopment does not involve any essential change in land use, the source of increased efficiency must be sought in the internal operation of retail firms. New retail structures may permit retailing to be done at lower unit cost because of lower costs of materials handling with one floor operation, easier loading and unloading for trucks, etc. Scale economies may occur because of indivisibilities of persons and equipment and large lot economies of purchasing and inventory. ${ }^{29}$ Since virtually all displaced businesses in the project area are single proprietorships, this cost saving may be significant. However, since total retail sales after renewal are expected to be substantially greater than before, attributing a cost reduction to all output is incorrect. Virtually, all the increase in Troy retail sales will be at the expense of modern suburban-type shopping malls and discount stores where costs are likely to be as low as in rebuilt Troy; any social cost saving is applicable only to the original level of Troy retail sales. ${ }^{30}$ The best way to approach the problem appears to be in terms of the gross profit margin on sales. This is the amount added by the retailer to the cost of his goods and out of which wages to employees, utility costs, rent, profit, taxes, etc. must be paid. Indeed, it is the "cost" of retailing the goods. Published ratios of gross profit indicate generally smaller markups for larger size stores within a particular retail store-type. ${ }^{31}$ We take the difference in this markup margin as the measure of improved efficiency. 
Ideally, we should like to know what the level of output would be in the project area in the absence of renewal and determine how much it would cost to produce the same output in the redevoloped area. Data limitations require us to proceed in a slightly different way. Based on the substantial number of shopping malls already in existence, it is possible to construct a hypothetical mall in terms of number and types of retail-service outlets found and their relative sizes. Estimates of income and population in the trading area permit sales estimates to be made for each line of retailing. This has been done for the Troy project by George Akohoshi, a respected consultant on these matters. ${ }^{32}$ Sales per store for twenty-five different types of stores in the new mall are compared with sales for pre-project establishments.

Using the 1967 Census of Business for Troy, average sales per store were calculated for the pre-project stores. Establishments displaced by renewal not usually found in regional shopping centers or of minor importance in them, such as real estate offices, are assumed to relocate off the project site into quarters similar to those vacated and thus generating no cost changes. The crucial sales lines are, of course, retailing of apparel, department stores, eating and drinking and miscellaneous lines like jewelry, drugs, etc. The apparel lines account for about one-half the number of displaced stores. A comparison of estimates of sales per mall store and Troy's 1967 figures reveal no essential difference in store sales in men's and ladies apparel. This is more significant if one considers that by 1970 there were probably fewer apparel shops while total sales remained about the same or grew slightly, as happened in 1963-67. Further, the data for pre-project sales are city wide, while CBD stores are likely to have greater per unit volume. Thus, there appears to be no increase in sales per store to generate cost economies in the apparel lines. The rest of the stores involved are eating and drinking places, service shops (barbers, beauty parlors), and a variety of retail stores such as jewelry, drugs, sporting goods, florists, liquor stores, etc. Census data made possible a direct comparison in eleven of seventeen lines (26 of 38 units). Only liquor, drugs, and eating and drinking places showed any significant differences in sales per store. For liquor stores, the cost reduction amounted to one percent of sales; for drugs, costs increase from 29.2 to 30.5 percent of sales; while for eating and drinking places costs rise from 51.4 to 55.8 per dollar of sales with the predicted increase in sales per firm. When these cost changes are multiplied by the number of mall stores and sales per old store a small overall increase in cost of retail sales per dollar occurs. Given the crudity of the data and technique, we assume no change in costs. In the six lines where direct comparison was not possible, total estimated sales was divided by the projected number of stores. The resulting sales per store was not essentially different from the 1967 census estimates when allowance is made for natural attrition in store numbers, rise in sales from 1967 to 1970 and downtown versus citywide sales per store.

It does not appear that the projected increase in sales per store will generate any significant scale economies. The falling portion of the reverse $\mathrm{J}$ long run average cost curve apparently flattens out at a fairly small level of output. Indeed, in some cases it appears $U$ shaped. This is not a surprising result. Given 
the vigor of retail competition, as the least cost output threshold grows ove time, the number of retail units in Troy (and nationwide) has steadily declinec as the weakest firms are forced out. The census indicates that the number 0 units has fallen while total sales has held roughly steady. Market forces seen to fully exploit available scale economies. These findings are contrary to the common view alleging the superiority of malls which focuses on their greate sales per square foot. This is not an indication of efficiency, per se, but rathe reflects the large amount of space available in Troy. As its population declinec and its competitive position eroded and market forces killed off marginal firms a good deal of retail space in Troy has become redundant. Urban renewal wil demolish about one million square feet of floor space and replace it with about sir hundred thousand square feet. The vast amount of space has little social cost anc rents cheaply, hence businessmen use it lavishly and sales per square foot were wel below national averages. This is efficient resource use.

\section{Changes in Fire and Crime Costs}

Given the age, type of construction and maintenance of project area build ings, urban renewal is likely to generate social cost savings in the form of re duced numbers of fires and fewer resources devoted to fire fighting. Based or data compiled by the Troy Fire Department, an average of nineteen building fires per year occurred in the commercial renewal area in the 1967-71 period..$^{33} \mathrm{Na}$ tionwide, the average amount of damage in mercantile and office fires was $\$ 535^{r}$ per incident. ${ }^{34}$ Renewal will construct fire-resistive, sprinklered buildings whos fire risk is low. Allowing for the staged demolition of old buildings and a twenty year economic life of the project commencing in 1980, a present value o $\$ 905,000$ in reduced damage results. This assumes that there will be no fires dur ing the twenty year period, whereas a few fires per year are more likely. In ad dition, we must estimate the saving in fire fighting costs resulting from this re duction in the number of fires. Fire department statistics indicate that durin the 1967-71 period, structural fires in the project area accounted for about ter percent of the structural fires fought by the fire station in whose jurisdiction the project area lies. Since about sixty percent of the workload of the fire de partment involves structural fires, a reduction of about six percent in the work load of the central station is possible. If this were reflected fully in a manpowe reduction, three fewer firemen per year would be needed. However, departmen data indicate that the fire companies serving the renewal area are significantly busier than companies stationed elsewhere in the city. The most likely result 0 the reduced workload is some easing of the burden on the overworked companies As a compromise, we assume two fewer firemen are needed over the twenty yea period of the project. This change in labor input is too small to affect capita expenditure. In presents value terms, the labor cost savings amounts to $\$ 85,000$

\section{Crime}

In order to ascertain the effect of urban renewal on crime, a cross sectior regression analysis of robberies and burglaries reported in 29 cities in New Yor State (excluding New York City) with population over 25,000 was used. 


$\begin{array}{rrr}\text { Robber } & =0.00850968 & \\ & +0.00000002 & \text { pop } \\ & (.00000001) & \\ & 0.00023813 & \text { nw } \\ & (0.00009425) & \\ & 0.00000170 & \text { Retpc } \\ & (0.00000087) & \\ & 0.58007765 & \text { Mgfpc } \\ & (0.48975503) & \\ & 0.00022892 & \text { oldhs } \\ & (0.00007707) & \\ & 0.001311901 & \text { poor } \\ & (0.00037173) & \end{array}$$$
\mathrm{R}^{2}=.6353
$$
Robber-robberies and burglaries per capita 1970
pop-city population 1970
Retpc-retail sales per capita in dollars 1967
Mfgpc-number of manufacturing firms per capita 1967
oldhs-percentage of housing units built before 1939 in 1970
poor-percentage of families and indi- viduals falling below official poverty line in 1970

All data from 1972 City and County Data Book.

Robberies and burglaries result, as a first approximation, from the confluence of motive and opportunity. People may be motivated to criminal acts by poverty, racism, frustration, mental illness, etc. In addition, suitable targets for criminal activity must be present, e.g. money, wealth, symbols of authority and establishment. Motivating forces are measured in the equation by the incidence of poverty and nonwhites. Population attempts to measure the alienation and anonymity caused by larger populations, in effect combining motivation and opportunity for crime. Opportunity is measured by the number of manufacturing firms per capita, as well as retail sales per capita. A priori, old housing could be a proxy for motive and need to steal, or as an index of things worth stealing from residences. Not surprisingly, since poverty or need is allowed for separately, old housing is inversely related to the number of robberies and burglaries, supporting the view that it measures the opportunity to steal. Given the complexity of crime, the fact that all coefficients but manufacturing are significant at the five percent level and the $\mathrm{R}^{2}$ is good for cross section data leads one to accept the results as meaningful. Renewal authorities expect an increase in the volume of retail sales of about thirty million dollars per year. From (2), this will increase the number of burglaries and robberies in Troy by about fifty per year, an eight percent rise over the 1970 rate, and a 4.5 percent increase in total serious crime. Income tax data on business losses sustained in burglaries and robberies indicate an average loss of $\$ 575$ per incident. ${ }^{35}$ The present value of this increased crime cost for twenty years is $\$ 245,000$, shown in Table 1 . In a strict sense such losses are largely income transfers (except where property is destroyed as part of the criminal act). But society has made such a strong negative value judgment about crime that any increase must be counted as a cost of the project.

Any additional resources devoted to the police department to combat this increased crime must also be included. For several reasons, however, we conclude that no measurable increase in police expenditures will occur. First, less than 
twenty percent of police time is spent preventing crime and apprehending criminals. Most time is spent providing service to the public (e.g. rescuing children) and dealing with traffic and auto accidents. ${ }^{36}$ In addition, Troy police patrols are carried out in a very rigid fashion. Each of the six police zones, including the renewal area zone, is patrolled by one radio car during each eight hour shift. This is in spite of the fact that the CBD-project area had twice as many serious crimes in 1967 than the next highest zone, even though it was the smallest in area and second smallest in population. Given this apparent insensitivity of resource deployment to criminal activity, we assume no change in police expenditures. ${ }^{37}$ After all, we are assuming only about one more crime per week, which is probably not enough of a change to provoke a response in public spending.

\section{Costs}

The criterion employed in indentifying project costs is simply the social value of resources used up or drawn from other uses by the project. Table 1 shows the relevant costs, discounted to Jan. 1, 1980, when the project is expected to be fully operational. Most of the items are obvious, but some explanation is necessary.

Value of structures demolished includes the estimated market value ${ }^{38}$ plus the discounted stream of taxes the structures would have yielded over their remaining life (estimated at ten years). This is done on the grounds that the private market capitalizes part of the social income stream paid as property taxes, which is lost when demolition occurs. Since we seek to measure net benefits directly, rather than via land value changes, only land drawn from alternative uses to project use should be considered a proper social cost. Thus land donated by the city from street rights-of-way is included as a cost, evaluated at adjacent private land prices. During construction, a good deal of the project land will lie vacant, and the foregone output (ten percent on market value) thus lost is included as a social cost, too.

Another cost item is the parking garages to be built and run by the city, an essential requirement for project success. Between 900 and 1400 spaces are to be provided and shoppers will be charged twenty cents per hour. In calculating the social cost of providing this parking, we value the site land at its former private market value, of $\$ 2.75$ to $\$ 4.74$ per square foot, not the urban renewal disposal price of $\$ 1.00$ per square foot. Assuming 1150 spaces to be actually built (at $\$ 4000$ each) and estimating the number of vehicle trips and parking revenues (two hours parking per trip) from the model in Part II, a net cost of about 3.6 million dollars in present value terms results. A forty year economic life for the garages is used in discounting. This figure understates the true cost because the value of structures demolished to make way for the garages is included with all other structures demolished.

One final item of cost requiring discussion is the forced liquidation of businesses caused by urban renewal. Contained within the project area are 110 businesses, of which 58 have already or intend to close their doors forever. ${ }^{39}$ Berry found a liquidation rate of about one third, which he concluded was not excessive when allowance is made for the naturally high mortality rate of small 


\section{TABLE 1}

Costs and Benefits of Downtown Renewal in Troy, New York (as of Jan. 1, 1980)

\section{Benefits}

Increased Efficiency of Shopping

Reduction in Cost of Retail Output

Reductions in Cost of Fires

Increased Crime

$\$ 1,812,382$

\section{Costs}

Value of Structures Demolished ${ }^{1}$

$\$ 14,514,898$

Parking Garages

$3,697,500$

Street Improvements

$3,908,520$

Moving Costs

603,941

Site Clearance

Property Acquisition, Management and Disposition

$1,319,823$

709,338

Administration, Survey and Planning

$2,705,440$

Land Donation by City

305,085

Return on Idle Land During Construction

181,500

Interest Income

Lost Output Due to Small Business Forced Liquidation

Source: calculations explained in text and data from Final Project Report, Troy Urban Renewal Agency

business and the declining economic status of renewal areas. ${ }^{40}$ Social costs are generated by liquidations if displaced factors of production are forced into less productive employments, involuntary unemployment or premature retirement. In Troy, the age of proprietors is the main reason why firms would choose to close rather than relocate. The first question is how many firms are forced out of existence that otherwise would have continued to operate. Concentrating on the retail/service sector which predominates in the project area, fifty-five retail and twenty-seven service outlets are being displaced. Twenty-nine retail and thirteen service firms will close forever. Not all these closings are due solely to urban renewal. From 1963 to 1967 the number of retail units in the Troy CBD declined 21.5 percent, ${ }^{41}$ more than twice the rate of decline for the city as a whole. Service units fell only 2.5 percent city wide in the same period. But the city seemed overstocked with service units when data on sales, income and wages per unit are compared to national averages. This situation probably reflects the age and lack of alternatives open to many service proprietors in Troy. In the 1967-72 period, the number of retail units in the project area fell about twenty-one percent, while service units fell forty-three percent. ${ }^{42}$ This shake-out of service firms seems 
compatible with the excess numbers noted above. In this light, their renewal mortality rate of forty-eight percent does not seem abnormal. However, the retail failure rate following displacement is almost twice the historical trend and cannot be dismissed so easily. At the historical rate of decline, about sixteen of the fifty-five retail firms would have closed by 1980, the project completion date. Thus, about thirteen retail shops appear to have suffered premature death due to urban renewal.

One way to measure the social cost involved in these premature failures is to look at the incomes earned by the proprietors forced out of business. So-called "In Lieu" payments by urban renewal to firms choosing to go out of business are based on the average income earned in any two years of four years preceding displacement. If the average is under $\$ 2500$, that is the sum paid. As income rises, the payment increases with a $\$ 10,000$ ceiling. Persons earning significantly less than the $\$ 7500$ average proprietorship income in Troy retailing are likely to have few alternative opportunities. Five retail units fell into this category by virtue of receiving the minimum displacement payments. Assuming a five year remaining average business life span, this amounts to $\$ 75,313$ (assuming $\$ 2500$ income per year) as of 1980 .

\section{Conclusion}

It appears from Table 1 that the renewal project in Troy uses up fifteen times more resource value than it creates. There does not seem to be any category of benefit omitted or error of computation likely to redress this imbalance. One implication is that urban markets may function with greater efficiency than hitherto thought likely.

Some may fault the approach to cost-benefit analysis taken in this paper as being too narrowly economic. This view holds that the ultimate justification for urban renewal, if it exists, must be found in its preservation of certain social values associated with a viable downtown area. Aside from the question of whether renewal does in fact preserve downtown, this argument is an aspect of the familiar charge that cost-benefit measures only the rabbit in a horse and rabbit stew. (The discussion of the demolition of historic buildings and the displacement of local merchants is partly an attempt to measure the horse, if only to gauge its tail.) The charge seems beside the point because it assumes, at least implicitly, that projects should be selected solely on economic grounds. Few cost-benefit analysts adhere to such a view. Further, it seems to ask economists to apologize for practicing their craft: analyzing resource allocation. Indeed, the argument could easily be turned around and economists, qua economists, might be enjoined to obey Harberger's dictum to consider only purely economic factors. To wit, "These [non-economic] elements . . . may be exceedingly important, perhaps the dominant factors governing any policy decision, but they are not a part of that package of expertise that distinguishes economists from the rest of humanity." ${ }^{\prime 3}$ Let me close by summarizing the findings in a manner that expresses my own view of the matter: the proponents of Troy downtown renewal now bear the burden of demonstrating that sufficiently important non economic benefits accrue from the project that warrant a net resource cost of twenty five million dollars. 


\section{FOOTNOTES}

1Troy Urban Renewal Agency, Uncle Sam Mall, Troy, N.Y., 1969 (mimeo), p. 8.

2See as examples: Jerome Rothenberg, Economic Evaluation of Urban Renewal (Washington D.C.: The Brookings Institution, 1967); Stephen D. Messner, "Urban Redevelopment in Indianapolis: A Benefit-Cost Analysis," Journal of Regional Science, Vol. 8, No. 2, 1968, pp. 149-158; James C. T. Mao, "Efficiency in Public Urban Renewal Expenditure Through Benefit-Cost Analysis," Journal of American Institute of Planners, March, 1966, pp. 95-107.

3John C. Weicher, Urban Renewal (Washington, D.C.: American Enterprise Institute, 1972), p. 67.

4See Bain J. L. Berry, Commercial Structure and Commercial Blight, (Chicago: Univ. of Chicago, Dept. of Geography, Research Paper No. 85, 1963), pp. 179-205.

${ }_{5}^{5}$ Debt amortization will come out of the surplus over variable cost, depending on the debt/equity ratio of the investment. External effects aside, social and private value will diverge by the amount of discounted taxes borne by the property.

6Homer Hoyt, Urban Land, July, 1969.

7E. J. Mishan, Cost-Benefit Analysis (New York: Praeger, 1971), pp. 316-321.

sRothenberg, op. cit., Ch. III and Otto Davis and Andrew Whinston, "The Economics of Urban Renewal," Law and Contemporary Problems, Winter 1961, pp. 105-117.

9In order to measure the improvement in project site land productivity, Rothenberg, op. cit., p. 124, employs the crucial assumption that offsite changes in land value equal onsite changes in locational advantage and that locational effects are the only source of offsite land value changes. No theoretical or empirical justification is offered for this procedure. The aproach employed here of measuring directly the sources of improved productivity, rather than via land value changes, seems less hazardous.

10John C. Weicher, "The Effect of Urban Renewal on Municipal Service Expenditures," Journal of Political Economy, February, 1972, pp. 86-101. 280 .

11James Heilbrun, Urban Economics and Public Policy (New York: St. Martin's Press, 1974), pp. 277-

\begin{tabular}{|c|c|c|c|c|c|c|}
\hline 12 Price $=$ & $\begin{array}{l}364.5086 \\
(22.7270)\end{array}$ & - & $\begin{array}{c}0.00002045 \\
(0.00079927)\end{array}$ & Sq. ft. & - & $\begin{array}{c}0.05266105 \\
(0.01690885)\end{array}$ \\
\hline Price $=$ & $\begin{array}{l}\mathbf{1 6 0 1 . 4 5 5 5} \\
(189.6947)\end{array}$ & - & $\begin{array}{c}7.95045721 \\
(14.11399555) \\
\mathrm{R}^{2}=.4269\end{array}$ & $\operatorname{lgsqf}$ & - & $\begin{array}{l}186.83515102 \\
(21.46844482)\end{array}$ \\
\hline lgpri $=$ & $\begin{array}{c}9.37535899 \\
(0.52890712)\end{array}$ & - & $\begin{array}{c}0.02641593 \\
(0.03935268) \\
\mathrm{R}^{2}=.4445\end{array}$ & $\operatorname{lgsqf}$ & - & $\begin{array}{c}0.53944267 \\
(0.05985837)\end{array}$ \\
\hline
\end{tabular}

${ }^{13}$ The theoretical foundation for these equations is developed by Edwin Mills, "The Value of Urban Land," in Harvey Perloff (ed), The Quality of the Urban Environment (Washington, D.C.: Resources for the Future, 1969), pp. 245-251.

${ }_{14}$ The New York Times, Sunday, July 14, 1974, p. 21.

${ }_{15}$ Brian J. L. Berry, Sandra Parsons and Rutherford H. Platt, The Impact of Urban Renewal on Small Business (Chicago: Center for Urban Studies, University of Chicago, 1968) pp. 77-131.

16See David L. Huff, "A Probabilistic Analysis of Shopping Center Trade Areas," Land Economics, February 1963, pp. 81-90. William J. Baumol and E. A. Ide, "Variety in Retailing," Management Science, October 1956, pp. $93-101$.

17 Ibid.

18David L. Huff, Determination of Intra-Urban Retail Trade Areas (Los Angeles, California: Real Estate Research Program, University of California, 1962).

19This data was kindly provided by William Heibert of the Capital District Transportation Study group of the New York State Department of Transportation, State Campus, Albany, New York.

${ }^{20}$ The walking time estimates are based on studies of parking and the proposed siting of the garages in Troy. See R. W. Stout, "Trends in CBD Parking Characteristics, 1956-1968," Highway Research Record 317, 1970, pp. 40-47, and G. Ergun, "Development of a Downtown Parking Model," Highway Research Record 369, 1971, pp. 118-134.

21Thomas C. Thomas and Gordon I. Thompson, "Value of Time Saved by Trip Purpose," Highway Research Record 369, 1971, pp. 104-117.

22Thomas and Thompson, Ibid, p. 111.

${ }^{23}$ Throughout this paper a social discount rate of ten percent is used. No particular justification of this rate is offered except that it seems a reasonable approximation of the social opportunity cost of capital in the 1970's, considering inflation and risk elements. The discount rate is not very important in evaluating the type of project under consideration, since the implicit choice is between the proposed project and the status-quo, both having similar time structures. Rejection or acceptance of a project hinges critically on the interest rate where alternatives with different time streams of costs and benefits are being considered. See Rothenberg, op. cit., pp. 107-110. 
${ }^{24}$ See "National Cooperative Highway Research Program Report," Highway Research Record 24, 1966, p. 115. The range of percentage shopping trips arriving by mass transit is 1-16 percent, with 3 percent the average.

25 Vehicle trips in the under $\$ 4000$ income bracket place zero value on a total of up to seven minutes social-recreation time and a .001 total for up to fourteen minutes. This compares to .008 and .278 cents, respectively, for the same time savings incurred in the 8-9999 income class. Thomas and Thompson, op. cit., p. 111.

26Three minutes was derived by comparing actual walking time and distances from parking found in CBD and suburban mall shopping centers. People exhibit a strong aversion to walking more than one block for all types of trip purposes, even in the face of large potential money savings. The disability of downtown parking stems therefore not from an actual shortage of space but rather the refusal of people to walk more than a block or so to reach their destination. In Troy, for example, a planning study in the early 1960's found about 4200 parking spaces of all types in the CBD and a peak hour demand estimated at only 3200. But most of the spaces were inconveniently located at the fringe of the business district. Thus, the shopper choosing between the typical suburban center and downtown in effect chooses between a virtual certainty of one block or less walking distance on one hand and only a probability on the other. In order to equate the two choices and compare the parking disability in terms of time, the probability is converted to a time certainty equivalent. Walking somewhat more than three blocks in any direction from Troy's main shopping intersection will bring one to the edge of the CBD and is virtually certain to assure a parking spot. Based on 1.5 minutes walking time per block, old Troy is three minutes more costly in terms of time than the typical shopping center in the suburbs. Shoppers in Troy should, therefore, be credited with this time saving benefit, too. One study (Ergun, op. cit) places the average value of time spent walking from parking for work trip at at least $\$ 4.50$ per hour, with potential savings up to $\$ 11.00$ per hour rejected, i.e. the person chose to pay rather than walk. Allowing for a somewhat lower value of walking time for shopping than for work still implies a value of, perhaps, twenty to forty cents for the three minutes saved. Since the parking garages being built in Troy will charge twenty cents per hour, the most sensible assumption seems to be that this fee equals the value of the time improvement. Therefore, the predicted parking revenues are set against the cost of the garages in calculating their net social cost. See R. W. Stout, "Trends in CBD Parking Characteristics, 1956-58," op. cit., and G. Ergun, "Development of a Downtown Parking Model," op. cit., also City of Troy New York Master Plan (prepared by Cadman, Klinger, Droste, 1962).

27 "National Cooperative Highway Research Program Report," op. cit.

2s Times Record, Troy, N.Y., February 15, 1974, p. 5.

29W. G. McClelland, Costs and Competition in Retailing (New York: St. Martin's, 1966) pp. $152-153$.

30 This assumes a reverse $J$ long run cost curve such that costs per unit in stores losing custom to Troy are not increased, i.e. non-Troy retailers remain on the horizontal portion of their cost curves. See Bob R. Holdren, The Structure of a Retail Market and Market Behavior of Retail Units (Englewood Cliffs, N.J.: Prentice-Hall, 1960), pp. 27-62.

31Leo Troy, Almanac of Business and Industrial Financial Ratios (Englewood Cliffs, N.J.: Prentice Hall, 1971).

${ }^{32}$ George T. Akahoshi, urban land economist, Land Utilization and Marketability Study Urban Renewal Projects C and D, Downtown Troy, New York, March, 1971, (mimeo).

${ }^{33}$ This data was compiled and organized by John Reilly of RRC International, Inc.

34"Fires and Fire Losses Classified," Fire Journal, Sept., 1973, pp. 23-26.

${ }^{35}$ Statistical Abstract of the United States, 1972, pp. 143, 151.

${ }^{36}$ G. E. Misner and R. B. Hoffman, Police Resource Allocation (Berkeley, Center for Planning and Development).

37In order to estimate changes in public service expenditures due to renewal, cross section regressions of police and fire expenditures per capita were run against a variety of plausible variables in many combinations. Unfortunately, no useful results were generated.

38Real estate values are based on assessed values adjusted to market value. Just prior to the start of the project, Troy underwent a complete reappraisal. In addition, the CBD was appraised a second time by the city assessor. These final figures, updated with actual sales information by the assessor, provide a fairly good indication of aggregate market values.

39Times Record, Troy, New York, Sept. 13, 1974.

${ }_{40}$ B. Berry, S. Parsons, et. al., op. cit., p. 3.

411963, 1967 Census of Business, Major Retail Centers, New York State. Also 1967 Census of Business, Vol. V, Selected Services-Area Statistics, New York State.

42Martin Dunbar, Relocation Director, Troy Urban Renewal Agency.

43Arnold C. Harberger, "Three Basic Postulates for Applied Welfare Economics: An Interpretive Essay," Journal of Economic Literature, September 1971, p. 785. 